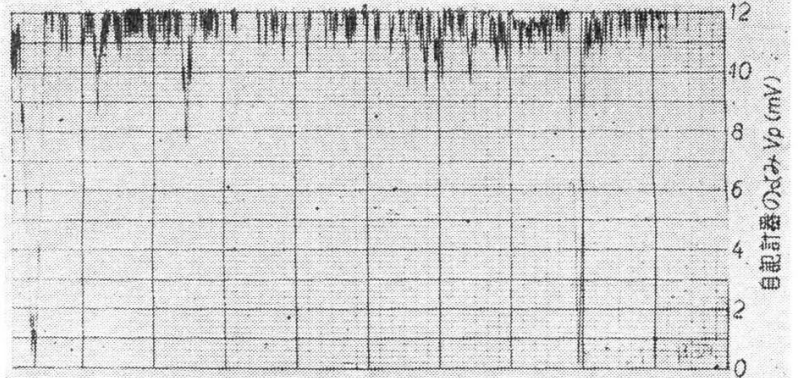

写真 6 鋼球を用いた場合の $\mathrm{E} の$ 測定結果，測定 される抵抗値の低いことを示す。
文献

（1）山崎正八郎，精密機械，20，130（1954）； 本誌, 10, 161 (1959)

（2）筆者, 精密機械，20，376（1954）；24, 136 (1958)；生産技術研究所報告, 7, 225 (1958)

(3) R. Holm, Electric Contacts Handbook, p. 35 (Springer, 1958)

\title{
アルミニウムおよびアルミニウム合金の電解研摩
}

松本誠臣*

\section{On Electropolishing of Aluminium and Its Alloys}

Studies on Electropolishing of Metals (Part 5)

\section{Shigeomi MATSUMOTO*}

As mechanical polishing of aluminium and its alloys is very difficult for their mildness, chemical and electro polishing are widely adopted for these metals, and various compositions of electropolishing bath, acidic or alkaline, for amphoteric aluminium have been suggested. But these baths are effective only for pure aluminium but not for alloys. The author, therefore, investigated electropolishing of various aluminium alloys. In this paper, the result of electropolishing in phosphoric acid-chromic acid bath which he proposes for carbon steels and copper alloys is reported.

(1) In phosphoric acid-chromic acid bath at comparatively low bath voltage-current density, electropolishing effects on aluminium alloys are good.

(2) Addition of chromic acid to the bath is effective to make oxydation or passivation of anode uniform, to prevent selective dissolution of added alloying elements and different structure of alloys, and to get smooth surface with luster. Silmin is well polished, silicon contained in it being oxidized and dissolved as colloidal silica.

(3) Electropolishing of cast material in the bath shows little effect but becomes a little effective after heat treatment such as quenching or annealing.

\section{1. 緒 論}

アルミニウム执よびアルミニウム合金は，アルミニウ ム自体の特質を利用して, 今日各種の精密計器, 機械部 品, 光学器機材料および日用雑貨などにかなり広い用途 があり，かつ，アルミニウム抒よ゙アルミニウム合金の 表面処理技術, すなわち, これら金属を陽極処理するこ

$\dagger$ 金属材料の電解研杽飞関する研究（第 5 報）

* 武蔵工業大学・坐㦃機械工学科 （東京都世田谷区玉川等々力町 1 丁目）

Musashi Institute of Thechnology
そによって, 強じんにして耐食性の優れた酸化皮膜を生 成させる技術の発達従って，さらに広い用途が開拓さ れてきていることは周知の事実である。本系合金の研摩 は, 本系合金が軟質金属材料の部類に属するため, 機械 的破摩はきわめて困難でむり，早くより電解研摩法ない 乙化学研摩法の研究が盛んに行なわれ, 研摩効果の上い 結果が得られて扣り, 今日本系合金に対してはほとんぞ これら研摩方法が用いられている。しかし, 従来の電解 研摩浴の多くは, 各種金属によってその研磨浴組成を異 にしている。者者は鉄鋼打よび銅合金の電解研摩浴とし て著者が提案していたリン酸一クロム酸系電解研摩浴に 
て研摩効果を検討したところ，本系合金に対してもきわ めてよい結果が得られたので, その研摩条件について報 告する。

本系合金に従来発表されている研摩浴について検討し て見ると，本系合金は，その特性として，鉄鋼，銅合金 そ異なり, 酸性掞よびアルカリ性の両者の浴が使用され ることである。田島氏 ${ }^{1)}$ はリン酸に, 寒天拉よびカセイ ソーダを添加した浴を提案しておられる。本系浴に执い て問題となる点は, 電圧一電流密度が高く, この結果浴 温が上昇しやすく, かつ, アルミニウム自体は陽極にお いて，他の金属に比して過熱されやすく，ピットを起こ す原因となり，鏡面を得ることが困難となっている。本 法の改良法として田島氏は均一溶解性を增し, 所要電流 密度を低下させる浴組成としてリン酸一硫酸一クロム酸 系浴を提案している。前記のリン酸一硫酸一クロム酸浴 に特いて田島氏は, 硫酸の添加は浴の電導性および均一 溶解性を増すが,酸食を起しやすく,これを防止する目的 でクロム酸を添加したとしている。著者はこのクロム酸 が陽極であるアルミニウム表面にきわめて薄く比較的丈 夫な酸化皮膜が生成するのを助け，この皮膜が陽極表面 の平滑化作用に役立つものであると考えるため, 著者が 鉄鋼および銅合金に対して使用したりン酸一クロム酸浴 が本アルミニウム系合金にも適用できるものと考光, 前 述のように研摩条件を見出した。

\section{2. 実 験 方 法}

浴組成は著者が鉄鋼および銅合金に使用したように， リン酸 $(\mathrm{S} . \mathrm{G}=1.7) 100 \mathrm{cc}$ に対して，クロム酸 $25 \mathrm{~g}$ を 添加し, $100^{\circ} \mathrm{C}$ 近くまで加熱, クロム酸を完全に溶解さ せたのち $70^{\circ} \mathrm{C}$ に保って用いた。実験装置および方法は 前報2 と同様である。本実験に使用せるアルミニウムお よびその合金の種類は第 1 表のとおりである。

\section{3. 実験結果および考察}

前緒論に执いても述べたようにアルミニウムはそれ自 体大気中にて, その表面に安定な酸化皮膜を作りやす い。この性質が電解研摩に执いて平滑光輝面を得ること を助けているすのと考兄られる。すなわち, リン酸に酸 化剈であるクロム酸を添加したものは, その陽極に分子 的厚サの酸化アルミニウムを形成し, 研摩效果を上年さ せるものと考光られる。

\section{3-1 アルミニウム}

純アルミニウムに対するリン酸一クロム酸電解研摩浴 は比較的, 低電流密度, 低電圧で行なわれた。すなわち その陽極に打ける举動を陽極電流密度一浴電圧特性曲線 で示すと第1図に示すようになる。電流密度, 浴電圧を 零より漸次上畀せしめると, 浴電圧が $2 \sim 10 \mathrm{~V}$ の範拥で
は, 陽極表面に酸化皮膜が形成され，浴電圧の上昇に対 して，電流の上悡はとんどなく，10V 以上に打いて陽 極の酸化皮膜は凸部上り破壊されて, 電流密度は徐々に 上界し陽極の溶解が始まる。16V 近傍になると電流計, 電圧計は周期的に振動が始まる。これは明らかに陽極に 和ける溶解々酸化皮膜の生成が交互に行なわれているも のと考えられる。しかしながら，この電流密度範囲に拈 いては, 陽極は局部的に加熱を受け, 本浴のように濃り ン酸液に打いては熱の対流, 伝導に上る陽極の冷却は少 なく，多少のカクハンに打いても陽極の加熱は防止でき なく, この加熱による影響も, この電流, 浴電圧の振動 に関係あるものと考它られる。研摩条件は 15V，20４0 $\mathrm{A} / \mathrm{dm}^{2}$ である。

アルミニウムは多く压延した板材として使用されるも のが多い。研摩効果は加工材についていえば, 加工度の 差異, 鋳造材についてい党ば鋳造の冷却速度, また鋳造 に抢いて使用する材料の純度などに影響を受ける。鋳造 材は粗大な結品と不純物により平滑面が得にくいのに対 し, 純度の高い板材はきわめて反射率の高、平滑光輝面 が得られた。

\section{3-2 ジュラルミン}

本系合金についての陽極特性曲線を第 2 図に示した。

\section{第 1 表}

\begin{tabular}{|c|c|c|c|c|}
\hline 試料 & 壾号 & 化学成分 & 処 & 注意事項 \\
\hline $\mathrm{A} l$ & A & & 延 & \\
\hline \multirow{3}{*}{$\begin{array}{c}シ \\
z \\
z \\
j \\
J \\
\vdots \\
\vdots \\
\vdots\end{array}$} & $\mathrm{AC}_{1}$ & \multirow{3}{*}{$\begin{array}{l}50 \% \mathrm{Cu} \\
0.15 \% \mathrm{Si}\end{array}$} & 砂型鋳造のまま & \\
\hline & $\mathrm{AC}_{2}$ & & 㱏型鋳造のまま & \\
\hline & $\mathrm{AC}_{3}$ & & $\begin{array}{l}510^{\circ} \mathrm{C} \text { より } 10 \mathrm{~h} \text { 水 } \\
\text { 冷 }\end{array}$ & 砂型の試料 \\
\hline \multirow{2}{*}{ ラ } & $\mathrm{ACS}_{1}$ & \multirow{5}{*}{$\begin{array}{l}4 \% \mathrm{Cu} \\
5 \% \mathrm{Si}\end{array}$} & 砂㤠鋳造のまま & 研 摩困 難 \\
\hline & $\mathrm{ACS}_{2}$ & & 金型鋳造のまま & $\begin{array}{l}\text { 吥摩 } \\
\text { 難 }\end{array}$ \\
\hline ウ & $\mathrm{ACS}_{3}$ & & $500^{\circ} \mathrm{C} 10 \mathrm{~h}$ 水冷 & 秒型 \\
\hline \multirow[t]{2}{*}{ タ } & $\mathrm{ACS}_{4}$ & & 同 上 & $\begin{array}{l}\text { 金型の試料 } \\
\text { 研摩良好 }\end{array}$ \\
\hline & $\mathrm{ACS}_{5}$ & & $\begin{array}{l}300^{\circ} \overline{\mathrm{C}} 10 \mathrm{~h} \text { 焼モ } \\
\text { ドシ }\end{array}$ & 同上 \\
\hline \multirow{2}{*}{$\begin{array}{l}\dot{y} \\
u \\
i \\
\dot{z}\end{array}$} & $\mathrm{ASM}_{1}$ & \multirow{2}{*}{$\begin{array}{l}12 \% \mathrm{Si} \\
0.42 \% \mathrm{Fe}\end{array}$} & 砂型鋳造のまま & $\beta$ \\
\hline & $\mathrm{ASM}_{2}$ & & $\begin{array}{l}200^{\circ} \mathrm{C} 10 \mathrm{~h} \text { 焼モ } \\
\text { ドシ }\end{array}$ & $\gamma$ \\
\hline \multirow{2}{*}{$\begin{array}{l}\mathrm{Y} \\
\text { 合 } \\
\text { 金 }\end{array}$} & $\mathrm{Y}_{1}$ & \multirow{2}{*}{$\begin{array}{c}4 \% \mathrm{Cu} \\
1.5 \% \mathrm{Mg} \\
27 \% \mathrm{Ni} \\
0.4 \% \mathrm{Fe}\end{array}$} & 砂型鋳造のまま & 研摩困難 \\
\hline & $\mathrm{Y}_{2}$ & & $\begin{array}{l}\text { 同.上の試料 } 400^{\circ} \mathrm{C} \\
2 \mathrm{~h} \text { 焼ナマシシ }\end{array}$ & 研摩良好 \\
\hline \multirow{2}{*}{$\begin{array}{l}\text { ヒナ } \\
\text { ドリ } \\
\text { ロウ } \\
\Delta\end{array}$} & $\mathrm{AM}_{1}$ & \multirow{2}{*}{$6 \% \mathrm{Mg}$} & \multirow{2}{*}{$\begin{array}{l}\text { 砂型鉡造のまま } \\
400^{\circ} \mathrm{C} 2 \mathrm{~h} \text { 秌ナ } \\
\text { マシ }\end{array}$} & 研摩困難 \\
\hline & $\mathrm{AM}_{2}$ & & & 研摩良好 \\
\hline$l \cdot \mathrm{Cu}$ & & $8 \% \mathrm{Cu}$ & 砂型鋳造のまま & 研 摩困難 \\
\hline
\end{tabular}




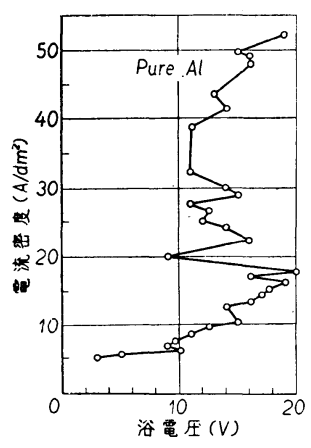

第 1 図

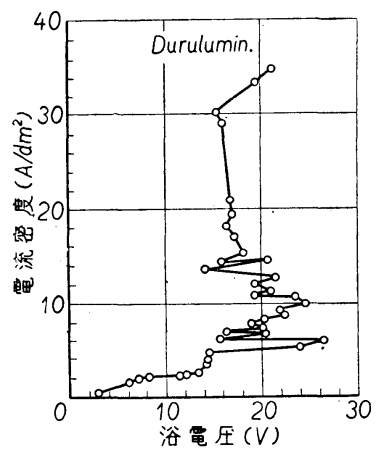

第 2 図

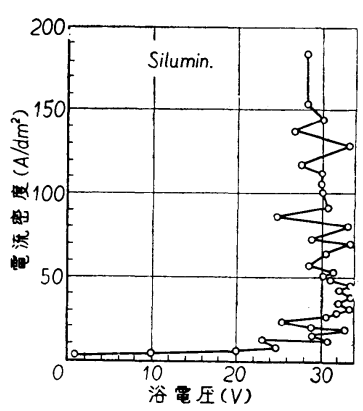

第 3 図
この図に示されるように，本系合金の特性曲線は前項で 述べたアルミニウムのそれそ類似している。すなわち， 浴電圧を漸次上䒜させても $10 \mathrm{~V}$ 前後までは陽極不働態に よる皮膜のため電流の上升は見られない。12V に浴電圧 が達すると電流は多少流れ始める。これは陽極表面に生 じた皮膜が部分的にハク離し始めるためと考えられる。 浴電圧が， $15 \mathrm{~V}$ 以上になるとアルミニウムの場合と同様 電圧計は $15 \mathrm{~V}$ と $20 \mathrm{~V}$ の間で周期的に振動しながら電流 が急激に流れ始め, 研摩条件領域に入る。研摩条件は $20 \mathrm{~V}-20 \sim 30 \mathrm{~A} / \mathrm{dm}^{2}$ である。

アルミニウム一銅系合金である本系合金は熱処理を施 すことによって，その諸性質が改善される。すなわち， 時効硬化, 焼入硬化, 焼モドシ硬化などが認められるが これらの処理によって研摩効果は当然左右されることが 考えられる。砂型および金型の鋳造材, および $510^{\circ} \mathrm{C}$, $10 \mathrm{~h}$ 保持し, 水中冷却したものについて, その研摩効果 を比較してみると, $\mathrm{CuAl}_{2}, \mathrm{Mg}_{2} \mathrm{Si}$ などの析出の状態が 研摩効果にきわめて影響あることがわかった。これら化 合物中で最も有害であると考えられるものは $\mathrm{Mg}_{2} \mathrm{Si}$ で ある。すなわち，これが多量に表面に析出しているもの は，陽極表面に黒色粉末状の不溶性塩が沈積する。これ は $\mathrm{Mg}_{2} \mathrm{Si}$ の影響と思われる。同じ鋳造材でも砂型のも のより金型の方が研摩効果がよかった。これは合金の凝 固速度による組織の粗細度によるものであると考兄られ る。暁入レしたものについては，鋳造したときの結晶粒 が成長して粗大化したものに比較して10hの加熱により 化合物の分布状態が均一化され研摩は容易となり, かつ 研摩効果は良好になった。

\section{3ー3 シルミン}

従来, 本系合金に対する電解研摩はきわめて困難視さ れて来ている。これは本合金中に含まれているケイ素に よるためであると考えられる。しかしながら，著者はヶ イ装銅の電解研摩に本りン酸一クロム酸浴を使用したと ころ, ケイ素鋼に含有されているケイ素元素は酸化ケイ 素として, コロイド状に溶出し, 研摩されることがわか
った。本合金に执いても同様なことが考光られる。陽極 特性曲線は第 3 図に示した。浴電圧 $25 \mathrm{~V}$ まではほとんど 浴電压の上犁に対して, 電流の上年は見られず, $25 \mathrm{~V}$ 以 上に沶いて, 陽極に蓄積された酸化アルミニゥム, 酸化 ケイ素は漸次ハク離, 溶出し, $30 \mathrm{~V}$ 前後に括いて, 浴電 圧は周期的に振動しながら電流の上年が見られ 30〜35V $-100 \mathrm{~A} / \mathrm{dm}^{2}$ 前後で研摩效果がきわ的良好となり平滑 面が得られた。

鋳造材は $\mathrm{Al}$ と Si の共晶組織であり研摩は困難であっ た。この理由はケイ素の多量共存によるものと考兄られ る。しかし, $200^{\circ} \mathrm{C}, 10 \mathrm{~h}$ の焼ナマシ処理により研摩効 果は著しく改善された。これは $\mathrm{Al}$ の結晶粒と非常に細 かい特殊な共晶組織になるためと考兄られ，これが鋳造 材と研摩効果を異にする理由と思われる。

\section{3-4 Y 合金}

本系合金はほほとんぞ鋳造状態のままで用いられるも のが多く, その研摩効果はシルミンと同樣に研摩は困難 視されている。その陽極特性曲線は第 4 図に示した。こ の傾向はシルミンときわめて類似して扣り, 研摩条件は 25V-80A $/ \mathrm{dm}^{2}$ である。

鋳造したままのものは研摩効果は法とんぞないが金相 学的応用には十分役立つ。鋳造材を $400^{\circ} \mathrm{C} 飞 2 \mathrm{~h}$ 保った のち, 暁ナマシしたものは研摩効果が 著しく改善され た。

\section{3-5 ラウタル}

本系合金も，シルミン，Y合金と同様に鋳造のまま使 用する場合が多い。鋳造材については研摩効果は悪く, これを $500^{\circ} \mathrm{C}$ で長時間加熱すると $\mathrm{CuAl}_{2}$ の化合物はほと んぞ $\mathrm{Al}$ の初晶中に固溶され, またケイ素の結晶はシル ミンのように針状結晶とはならず, 丸味を帯びる。それ ゆ穴，研摩は容易となる。陽極に淤ける特性曲線は第 5 図に示すと抢りである。周期振動はきわめて大きく10〜 $20 \mathrm{~V}$ の範国で振動しながら研摩される。研摩条件は $15 \mathrm{~V}$ —150〜 170A $/ \mathrm{dm}^{2}$ である。

研摩效果の順は $510^{\circ} \mathrm{C} て ゙ 10 \mathrm{~h}$ 保ち後水冷した焙入材, 


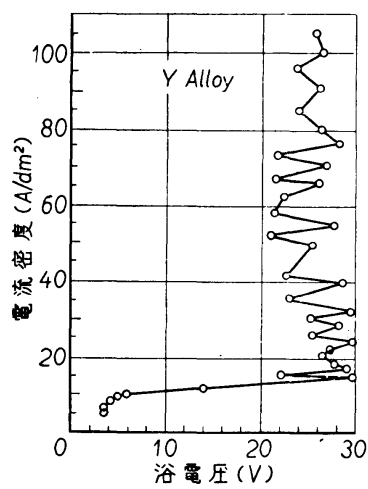

第 4 図

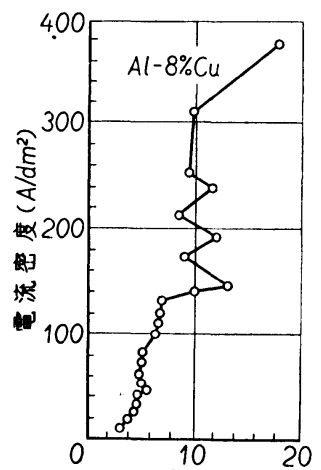

浴覃圧 $(V)$
第 5 図

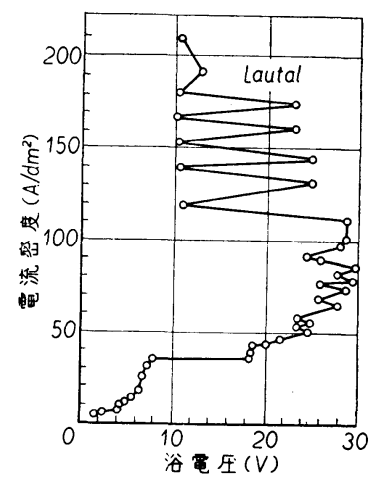

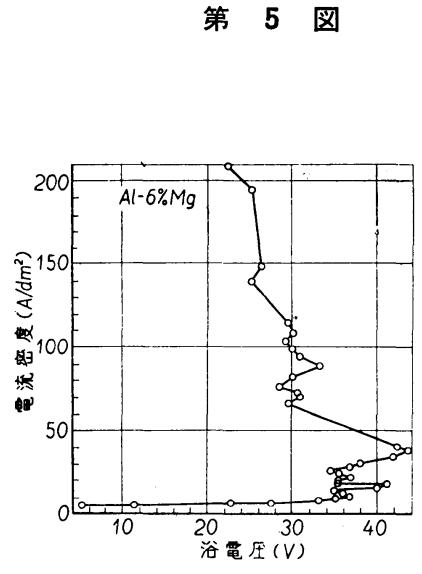

第 7 図

合金に比して,不働態化皮膜は丈夫であり， これを破壊するためには高電圧を必要とす ることが考兄られる。この陽極特性曲線は 第7図に示したように 浴電圧が 40Vに達す るまでは, 電流の上升は徐々であり, $40 \mathrm{~V}$ 以上に揖いては電流の急激の上年に伴ない 浴電圧は降下し， $20 \mathrm{~V}-50 \sim 70 \mathrm{~A} / \mathrm{dm}^{2}$ で 研摩領域に入る。

本系合金比いて子鋳造材の研摩効果は 覀く, $400^{\circ} \mathrm{C} て ゙ 2 \mathrm{~h}$ 保ったのち, 焼ナマ シしたものは研摩は容易となる。

\section{4. 結 論}

従来, アルミニウム系合金の電解研摩に 関しては主として純度の高いアルミニウム 単体に限られていたが，他のアルミニウム 合金についてる，その研摩効果执よび研摩 条件について検討してみた。その結果を要 約すると次のそ扣りである。

(1) リン酸一クロム酸浴飞抲いて，アル ミニウム抢よびアルミニウム合金は比較的 低浴電圧一低電流密度で研摩することが可 能である。

(2) ケイ素元素を含むシルミンなどのア ルミニウム合金において，ケイ素元素は不 $300^{\circ} \mathrm{C}$ より焼ナマシしたものがこれに次ぎ鋳造材でも金 型のものの方が砂型より研摩効果は良好であった。

\section{3-6 Al - Cu 合金}

アルミニウム中へ銅の固溶する範囲は $510^{\circ} \mathrm{C} て ゙ ~ 47 \%$ 内 外であるが，8\%銅を添加したものを本実験に採用した。 本系合金の陽極特性曲線は第 6 図に示した。他のアルミ ニウム合金に比して比較的低浴電圧にて周期的振動が見 られ, 6V以上においては浴電圧のわずかな上年に対し， 電流の增加率はさわめて大となる。これは高電流による 陽極括よび一部の液の局部的加熱の影響が大いにあるも のと考えられる。この影響による条コン，扣よび局部過 熱により部分的な最りを生ずる。このため研摩条件は $10 \mathrm{~V} 150 \sim 200 \mathrm{~A} / \mathrm{dm}^{2}$ がよい。

$8 \% \mathrm{Cu}$ 合金は最も鋳造しやすく，鋳造材として広く 利用されているが，研摩効果はあまりよくないが組織検 査にかなり利用できるものと考兄られる。焼入レしたも のは，その研摩面は真珠のような色沢を有する。

\section{3-7 $\mathrm{Al}-\mathrm{Mg}$ 合金}

本系合金が耐食性合金であるため，他のアルミニウム

溶性の酸化ケイ素を生じ, 陽極表面に蓄積されるが，こ れは水洗により簡単に除去でき，またコロイド状となり 溶出し, 陽極は比較的平滑飞研摩される。研摩効果は陽 極表面に析出しているケイ素元素打よびこの金属間化合 物の量技よび分布に左右される。

(3) アルミニウム単体については, きわめて反射率の よい平滑, 光輝面が得られた。各種合金については鋳造 材はほとんぞ研摩効果がなく, 組織検查に役立つ範囲に 限定されるが，これら鋳造材を焼入レ，焼ナマシ，など を行ならことにより研摩効果が著しく改善された。

最後に本研究に種々ご指導とご援助とを下さった, 武 蔵工業大学 呂戊辰教授, ならびに日本大学理工学部 岡俊平教授に対し深謝の意を表する。

(1960.9.15 受理)

\section{文献}

（1）田島栄, 電解研摩と化学研摩, p.32. (1958, 産業困 書)

(2) 松本誠臣，本誌，11，351（1960） 